PEDROSA CE; ANDRADE JÚNIOR VC; PEREIRA RC; DORNAS MFS; AZEVEDO AM; FERREIRA MAM. 2015. Yield and quality of wilted sweet potato vines and its silages. Horticultura Brasileira 33: 283-289. DOI: http://dx.doi.org/10.1590/S0102-053620150000300002

\title{
Yield and quality of wilted sweet potato vines and its silages
}

\author{
Carlos E Pedrosa; Valter C Andrade Júnior; Rosana C Pereira; Marcus FS Dornas; Alcinei M Azevedo; \\ Marcos AM Ferreira \\ Universidade Federal dos Vales do Jequitinhonha e Mucuri, Diamantina-MG, Brasil; carlosenrrik@yahoo.com.br; valterjr15@gmail. \\ com; rosanac_pereira@yahoo.com.br; mfsdornas@yahoo.com.br; alcineimistico@hotmail.com; marcosmamf23@yahoo.com.br
}

\begin{abstract}
Sweet potato is widely used for human consumption, but has also potential for its use in animal feeding. In this study we evaluated yield and quality as forage of wilted vines of various sweet potato genotypes and selected the most suitable for silage. Fifteen genotypes were evaluated (BD-31TO, BD-26, BD-13, BD-17, BD-22, BD-24, BD-54, BD-56, BD-69, BD-43, BD-44, BD-46, BD-52, BD-35, and cultivar Brazlândia Rosada), in a randomized complete blocks design, with three replications. At harvest we determined the yield of fresh matter and subsequently dry matter of vines. After 190 days of ensilage, we determined the concentrations of dry matter, crude protein, neutral and acid detergent fiber, lignin, ash, soluble carbohydrates in both vines and its silages; buffering and fermentative capacities of vines, and $\mathrm{pH}$ of silages. Genotypes BD-13, BD-17, BD-54, BD-56, BD-43, BD-44, BD-46, and BD-52 showed medium to high yield of fresh and dry matter. There were significant differences among genotypes in all studied bromatological characteristics, except for carbohydrate concentrations in wilted vines and their silages. Considering wilted vines, genotypes BD-26, BD-13, BD-56, BD-46, BD-35 and cultivar Brazlândia Rosada were those with the most suitable bromatological composition for animal feeding. Genotype BD-56 was the most appropriate for silage production.
\end{abstract}

Keywords: Ipomoea batatas, forage, bromatology, silage, genotype evaluation.

\section{RESUMO}

Produtividade e qualidade de ramas emurchecidas de batatadoce e de suas silagens

A batata-doce é bastante utilizada para a alimentação humana, mas tem também reconhecido potencial para utilização na alimentação animal. Foram avaliados a produtividade e a qualidade de ramas emurchecidas de 15 genótipos de batata-doce (BD-31TO, BD-26, BD13, BD-17, BD-22, BD-24, BD-54, BD-56, BD-69, BD-43, BD-44, BD-46, BD-52, BD-35 e a cultivar Brazlândia Rosada) e selecionados os mais indicados à produção de silagem, em delineamento de blocos ao acaso com três repetições. Na colheita foram determinadas a produtividade de massa verde e posteriormente de massa seca de ramas. Após 190 dias de ensilagem foram determinadas as concentrações de matéria seca, proteína bruta, fibra em detergente neutro e ácido, lignina, cinzas, carboidratos solúveis das ramas e de suas silagens; capacidade tampão e capacidade fermentativa das ramas e $\mathrm{pH}$ das silagens. Os genótipos BD-13, BD-17, BD-54, BD-56, BD-43, BD44, BD-46, BD-52 apresentaram produtividade de massa verde e seca das ramas de média a alta. Foram observadas diferenças significativas entre genótipos nas características bromatológicas estudadas, exceto para as concentrações de carboidratos das ramas emurchecidas e de suas silagens. Considerando as ramas emurchecidas, os genótipos BD26, BD-13, BD-56, BD-46, BD-35 e Brazlândia Rosada apresentam a composição bromatológica mais adequada à alimentação animal. Já para produção de silagens, o genótipo BD-56 foi o mais indicado.

Palavras-chave: Ipomoea batatas, forragem, bromatologia, silagem, avaliação de genótipos.

(Recebido para publicação em 12 de março de 2014; aceito em 3 de fevereiro de 2015) (Received ob March 12, 2014; accepted on February 3, 2015)

$\mathrm{S}$ weet potatoes (Ipomoea batatas) is a key crop in family farming systems, since it is easy to grow, widely adapted to various soil and climatic conditions, and tolerant to drought. In addition, it has a relative low production cost when compared to other vegetable crops. The extensive use of sweet potato roots is well-known. Conversely, the use of other plant parts is quite unusual, although vines can be successfully exploited in animal feeding
(Dornas, 2012; Figueiredo et al., 2012). According to Monteiro et al. (2007), sweet potato vines have satisfactory concentrations of crude protein and high fermentative capacity. Countries such as China and Vietnam use sweet potato vines alone or in combination with roots to feed pigs, in fresh or as silage, while in Brazil, vines are considered useless and therefore thrown away on the farm (Monteiro et al., 2007).

To encourage the use of sweet potato vines and their silage, we must produce research results to back up its advantages and to show the means to improve its already high quality as forage. Vine wilting or pre-drying is one of the cheapest ways for farmers to increase the feeding quality of sweet potato vines. Vine wilting aims at adjusting the forage dry matter content to $25-30 \%$, ideal values for silage production (Freitas et al., 2006). Since this practice results in higher 
quality silage (Loures et al., 2005), it is interesting to develop studies to evaluate its effect on the quality of sweet potato vines and their silages.

Thus, the objective of this study was to evaluate yield and quality of wilted vines of different sweet potato genotypes and to select the most suitable for silage production.

\section{MATERIAL AND METHODS}

We carried out the experiment at the Experimental Farm Rio Manso, Federal University of the Valleys of Jequitinhonha and Mucuri, in Couto Magalhães de Minas, Minas Gerais State, Brazil, between December 16, 2010, and August 03, 2011. The region has a tropical climate, with a dry season from April to September. During the experiment, temperatures varied between 17 and $35^{\circ} \mathrm{C}$, while the annual average is $19.4^{\circ} \mathrm{C}$. The soil is a Typic Hapludox (Embrapa, 2006), with the following characteristics: $\mathrm{pH}=5.6$ (in water); $\mathrm{P}=2.0 \mathrm{mg} / \mathrm{dm}^{3} ; \mathrm{K}=60 \mathrm{mg} / \mathrm{dm}^{3}$ (Mehlich 1); $\mathrm{Al}=0.14 \mathrm{cmol}_{\mathrm{c}} / \mathrm{dm}^{3} ; \mathrm{Ca}=$ $1.10 \mathrm{cmol}_{\mathrm{c}} / \mathrm{dm}^{3} ; \mathrm{Mg}=0.52 \mathrm{cmol} / \mathrm{dm}^{3}$ $(\mathrm{KCl}$ extractor $1 \mathrm{~mol} / \mathrm{L}) ; \mathrm{H}+\mathrm{Al}=3.0$ $\mathrm{cmol}_{\mathrm{c}} / \mathrm{dm}^{3} ; \mathrm{CEC}=4.8 \mathrm{cmol}_{\mathrm{c}} / \mathrm{dm}^{3}$; base saturation $=37 \%$; aluminum saturation $=7 \%$; organic matter $=0.8 \mathrm{dag} / \mathrm{kg}$ (Walkey-Black method); sand $=57 \mathrm{dag} /$ $\mathrm{kg}$; silt $=17 \mathrm{dag} / \mathrm{kg}$; clay $=26 \mathrm{dag} / \mathrm{kg}$.

We used dolomitic limestone applied 60 days before planting to adjust soil conditions, according to the soil chemical analysis and following (Alvares et al., 1999) recommendations. Plots consisted of two $3.0 \mathrm{~m}$ long furrows, with spacing of $0.90 \mathrm{~m}$ between furrows and 0.30 $\mathrm{m}$ between plants, making 20-plant plots. For planting fertilization, again we followed Alvares et al. (1999) recommendations: $30-180-60 \mathrm{~kg} / \mathrm{ha}$ of $\mathrm{N}-\mathrm{P}_{2} \mathrm{O}_{5}-\mathrm{K}_{2} \mathrm{O}$ respectively, using as sources ammonium sulphate, single superphosphate and potassium chloride, and; $10 \mathrm{t} /$ ha of tanned bovine manure manually spread and incorporated into the furrows. Topdressing, $30 \mathrm{~kg} / \mathrm{ha}$ of $\mathrm{N}$, took place 30 days after planting.

The experimental design was completely randomized blocks. Treatments consisted of fifteen sweet potato genotypes (BD-31TO, BD-26, BD-13, BD-17, BD-22, BD-24, BD-54, BD-56, BD-69, BD-43, BD-44, BD-46, BD-52, BD-35 and cultivar Brazlândia Rosada), with three repetitions. Genotypes were selected from the UFVJM germplasm bank. Cultivar Brazlândia Rosada was used as control.

We planted the seedlings in December 2010 and harvested the plants 230 days after, cutting all vines of all plants in the plot at the ground level. The yield of fresh mass of vines (FMV) corresponded to the weight of the vines, with the results expressed in $\mathrm{t} / \mathrm{ha}$. Vines were dried in an oven with forced ventilation at $60^{\circ} \mathrm{C}$ and subsequently at $105^{\circ} \mathrm{C}$ until constant weight to obtain the dry matter concentration (DM), with results expressed in $\mathrm{g} / \mathrm{kg}$. The yield of dry mass of vines (DMV) was calculated by multiplying FMV by DM, with results expressed in $\mathrm{t} / \mathrm{ha}$.

We left the fresh-cut vines, with average moisture content of $79 \%$, in the open field, under the sun, for 24 hours, with day and night average temperatures of 25 and $12^{\circ} \mathrm{C}$, respectively, to reduce the moisture content. After wilting, we chopped the vines, at this point with average moisture of $70.6 \%$, in 2 to $3-\mathrm{cm}$ pieces using a grass disintegrator. For each experimental plot, we produced two samples and froze one to use later for determining buffer capacity. The other sample was weighted and oven dried with forced ventilation at $60^{\circ} \mathrm{C}$ until constant weight. After that, we ground the sample in a Willey mill, 1-mm sieve, and stored it in a hermetically sealed jar for chemical analysis. To produce the silages, chopped vines were ensiled for 190 days in PVC silos provided with Bunsen valves.

Upon opening the silos, we homogenized the silage and discarded the ends. In fresh samples, we determined $\mathrm{pH}$ on a digital $\mathrm{pH}$ meter, using $15 \mathrm{~g}$ samples homogenized with $50 \mathrm{~mL}$ of deionized water. Silage samples were also oven dried with forced ventilation at $60^{\circ} \mathrm{C}$ and ground in Wiley mill, 1$\mathrm{mm}$ sieve.

On wilted vines and respective silages, we determined the concentrations of dry matter (DM), crude protein \{total protein $(\mathrm{CP})\}$, neutral $\{$ fiber related to the voluntary intake (NDF) $\}$ and acid \{low digestibility fiber, when high limits intake (ADF) $\}$ detergent fiber, lignin \{useless forage component, direct related to low quality (LIG) $\}$ and ash mineral residue after burning the organic matter (ASH)\}, according to the methods described by Silva \& Queiroz (2002). Results were expressed in $\mathrm{g} / \mathrm{kg}$ of DM. We extracted the water soluble carbohydrates (WSC) in 80\% ethanol \{Valadares Filho (1981), cited by Pesce et al. (2000)\}.

In wilted vines, we determined the buffering (BC) (tolerance of the material to changes in $\mathrm{pH}$ ), as Playne \& McDonald (1966), and the fermentative capacities (FC) (forage suitability to fermentation; the higher FC, the lower the loss of quality in the silage), calculated according to the equation proposed by Kaiser et al. (2002), cited by Coan et al. (2007): FC $=\mathrm{DM}+8 \times$ (SC/BC); DMS expressed in \%, CS in $\%$ of $\mathrm{DM}$, and $\mathrm{BC}$ in $\mathrm{mg}$ of $\mathrm{HCl} / 100 \mathrm{~g}$ of DM.

Data were submitted to analysis of variance using the statistical software Sisvar, v. 4.6 (Ferreira, 2011). The Scott Knott test was used at 5\% probability to compare the means of treatment clusters.

\section{RESULTS AND DISCUSSION}

Genotypes differed significantly from each other in yield of both fresh (FMV) and dry mass of vines (DMV), as well as in dry matter concentration of vines in natura (DM in natura) (Table 1).

FMV ranged from 7.3 to $45.4 \mathrm{t} /$ ha. Genotypes BD-54, BD-56, BD-44, and DB-52 were the top yielding, with FMV above $40.0 \mathrm{t} / \mathrm{ha}$. Genotypes with the lowest yields, among them cultivar Brazlândia Rosada, had FMV below 25 t/ha. FMV values observed currently were lower than those obtained by Viana et al. (2011), in Diamantina, with a vegetative cycle of 150 days, which averaged $52.77 \mathrm{t} / \mathrm{ha}$. Conversely, Cardoso et al. (2005) found FMV values much lower than ours, ranging from 1.4 to $14.1 \mathrm{t} / \mathrm{ha}$, for vines harvested seven months after planting. These results indicated that, besides plant cycle 
Table 1. FMV= yield of fresh mass of vines (produtividade de massa verde das ramas), DM in natura $=$ dry matter concentration in vines in natura (concentração de matéria seca in natura) and DMV= yield of dry mass of vines (produtividade de massa seca de ramas) of 15 sweet potato genotypes (de 15 genótipos de batata-doce). Diamantina, UFVJM, 2011.

\begin{tabular}{lccc}
\hline Genotypes & FMV*(t/ha) & DM in natura* $(\mathbf{g} / \mathbf{k g})$ & $\mathbf{D M V * ( t / h a )}$ \\
\hline BD-31TO & $23.4 \mathrm{c}$ & $201 \mathrm{~b}$ & $4.7 \mathrm{~b}$ \\
BD-26 & $11.3 \mathrm{c}$ & $244 \mathrm{a}$ & $2.9 \mathrm{~b}$ \\
BD-13 & $31.4 \mathrm{~b}$ & $207 \mathrm{~b}$ & $6.4 \mathrm{a}$ \\
BD-17 & $31.5 \mathrm{~b}$ & $230 \mathrm{a}$ & $7.2 \mathrm{a}$ \\
BD-22 & $17.2 \mathrm{c}$ & $225 \mathrm{a}$ & $4.0 \mathrm{~b}$ \\
BD-24 & $18.8 \mathrm{c}$ & $219 \mathrm{a}$ & $4.2 \mathrm{~b}$ \\
BD-54 & $41.7 \mathrm{a}$ & $198 \mathrm{~b}$ & $8.3 \mathrm{a}$ \\
BD-56 & $45.4 \mathrm{a}$ & $174 \mathrm{~b}$ & $7.7 \mathrm{a}$ \\
BD-69 & $24.6 \mathrm{c}$ & $206 \mathrm{~b}$ & $4.9 \mathrm{~b}$ \\
BD-43 & $33.5 \mathrm{~b}$ & $187 \mathrm{~b}$ & $6.1 \mathrm{a}$ \\
BD-44 & $41.4 \mathrm{a}$ & $189 \mathrm{~b}$ & $7.8 \mathrm{a}$ \\
BD-46 & $29.4 \mathrm{~b}$ & $193 \mathrm{~b}$ & $5.6 \mathrm{a}$ \\
BD-52 & $41.8 \mathrm{a}$ & $191 \mathrm{~b}$ & $8.0 \mathrm{a}$ \\
BD-35 & $13.7 \mathrm{c}$ & $244 \mathrm{a}$ & $3.2 \mathrm{~b}$ \\
Brazlândia Rosada & $7.3 \mathrm{c}$ & $235 \mathrm{a}$ & $1.4 \mathrm{~b}$ \\
\hline Average & 27.5 & 210 & 5.5 \\
CV(\%) & 31.6 & 15.7 & 31.7 \\
\hline
\end{tabular}

*Significant, F test, $\mathrm{p}>0.05$; means followed by the same letter in the column do not differ from each other, Scott Knott test, $\mathrm{p}>0.05$ (significativo, teste de F, $\mathrm{p}>0$, 05; médias seguidas de mesma letra na coluna não diferem entre si, teste de Scott Knott, p>0,05).

(Azevedo et al., 2014), other factors such as edafoclimatic conditions, vine fenological stage at harvest and crop location, have strong influence over FMV.

Dry matter concentration in vines in natura (DM in natura) varied among genotypes from 174 to $244 \mathrm{~g} / \mathrm{kg}$, with an average of $210 \mathrm{~g} / \mathrm{kg}$. In spite of the variation, in all genotypes DM in natura was below the recommended value for using vines for silage, which ranges from 250 to $300 \mathrm{~g} / \mathrm{kg}$ (Woolford, 1984). This result stresses the need for vine wilting to adjust DM concentration to silage requirements.

Genotypes BD-13, BD-17, BD54, BD-56, BD-43, BD-44, BD-46, and $\mathrm{BD}-52$ had the highest values for yield of dry mass of vines (DMV), significantly outyielding even cultivar Brazlândia Rosada. The variation we found for DMV (1.4 to $8.3 \mathrm{t} / \mathrm{ha}$ ) is similar to those found by Viana et al. (2011), who evaluated sweet potato genotypes 180 days after planting (3.7 to $7.4 \mathrm{t} / \mathrm{ha}$ ); Figueiredo et al. (2012), who found DMV ranging from 3.05 to $4.95 \mathrm{t} / \mathrm{ha}$ for vines harvested 163 days after planting, and; Andrade Junior et al. (2012), who found values from 1.2 to $3.5 \mathrm{t} / \mathrm{ha}, 180$ days after planting. Dornas (2012), evaluating genotypes BD-31TO, BD-43, BD-23, BD-08, BD-25, BD-38, and cultivar Brazlândia Roxa, harvested 150 days after planting, found DMV ranging from 4.2 to $7.9 \mathrm{t} / \mathrm{ha}$, similar to the values we are presently reporting for vines harvested 230 days after planting. This may indicate a strong slowdown in vine dry mass accumulation, 150 days after planting, when plants start losing leaves and other parts.

Genotypes differed significantly from each other on the concentrations of dry matter (DM), crude protein (CP), neutral (NDF) and acid detergent fiber (ADF), lignin (LIG), ashes (ASH) and buffer (BC) and fermentative capacity (FC) of wilted branches. No significant differences were observed for water soluble carbohydrates (WSC) (Table 2).

DM in wilted vines ranged from 226 to $341 \mathrm{~g} / \mathrm{kg}$, which is higher than what was reported by Viana et al. (2011), 168.7 to $213.9 \mathrm{~g} / \mathrm{kg}$ for wilted vines kept under shelter for twelve days. Genotypes BD-26, BD-22, BD-35, and cultivar Brazlândia Rosada showed the highest values, exceeding $330 \mathrm{~g} /$ $\mathrm{kg}$. We also observed that, except for genotype BD-44, which scored $226 \mathrm{~g} /$ $\mathrm{kg}$ of DM, all other genotypes had DM content greater than $250 \mathrm{~g} / \mathrm{kg}$, proving the efficiency of the 24-hour wilting period in adjusting DM concentration to values recommended to use vines for silage (Woolford, 1984).

Crude protein content $(\mathrm{CP})$ in wilted vines ranged from 108 to $131 \mathrm{~g} / \mathrm{kg}$ of $\mathrm{DM}$, with an average of $120 \mathrm{~g} / \mathrm{kg}$. These values are similar to those obtained by Dornas (2012) evaluating vines of seven genotypes wilted for 48 hours, who reported an average of $119 \mathrm{~g} /$ $\mathrm{kg}$ of CP and of DM. In this research, all genotypes meet the protein needs of ruminants, since the lowest CP content we found was higher than 70 $\mathrm{g} / \mathrm{kg}$. According to Van Soest (1994), diets containing less than $70 \mathrm{~g} / \mathrm{kg} \mathrm{CP}$ or with low nitrogen availability may have reduced digestibility and thus less consumption, due to the slow passage of food through the rumen.

We did not observe significant differences among genotypes for the concentration of water soluble carbohydrates (WSC), which averaged $104 \mathrm{~g} / \mathrm{kg}$ of DM. The average value we found in wilted vines in this study was much higher than what Haigh (1990) reports as necessary to obtain intense lactic fermentation during the ensilage process ( 25 to $30 \mathrm{~g} / \mathrm{kg}$ WSC in the forage material).

Genotypes BD-17, BD-54, BD56 , BD-69, and BD-43 had the lowest values for the neutral detergent fiber (NDF), less than $460 \mathrm{~g} / \mathrm{kg}$ of DM. Dornas (2012), when studying vine wilting in sweet potato, found an average value of $479 \mathrm{~g} / \mathrm{kg}$ of NDF in $\mathrm{DM}$ in vines wilted for 48 hours. The highest concentration we found was $491 \mathrm{~g} / \mathrm{kg}^{-1}$ of DM (cultivar Brazlândia Rosada), even though below the limit recommended by Van Soest (1994). This author states that NDF contents higher than $600 \mathrm{~g} / \mathrm{kg}$ correlate negatively with voluntary DM intake by animals. 
Table 2. $\mathrm{DM}=$ average concentration of dry matter (concentração média de matéria seca), $\mathrm{CP}=$ crude protein (proteína bruta), WSC= water soluble carbohydrates (carboidratos solúveis), $\mathrm{NDF}=$ neutral and $\mathrm{ADF}=$ acid detergent fiber (fibra em detergente neutro ácido), $\mathrm{LIG}=$ lignin (lignina), $\mathrm{ASH}=$ ashes (cinzas) and $\mathrm{BC}=$ buffering and $\mathrm{FC}=$ fermentative capacity (e capacidades tampão e fermentativa) of vines of 15 sweet potato genotypes wilted for 24 hours under the sun (de ramas de 15 genótipos de batata-doce emurchecidas por 24 horas em pleno sol). Diamantina, UFVJM, 2011.

\begin{tabular}{|c|c|c|c|c|c|c|c|c|c|}
\hline \multirow{2}{*}{ Genotype } & \multirow{2}{*}{$\begin{array}{c}D M *(g / \\
\text { kg) }\end{array}$} & $\mathrm{CP}^{*}$ & $\mathrm{WSC}^{\mathrm{ns}}$ & NDF* & ADF* & LIG* & ASH* & \multirow{2}{*}{ BC* } & \multirow{2}{*}{$\mathrm{FC}^{*}$} \\
\hline & & \multicolumn{6}{|c|}{$(\mathrm{g} / \mathrm{kg} \mathrm{MS})$} & & \\
\hline BD-31TO & $287 \mathrm{c}$ & $114 \mathrm{~b}$ & 113 & $472 \mathrm{~b}$ & $348 \mathrm{~b}$ & $96 \mathrm{e}$ & $83 \mathrm{a}$ & $4.1 \mathrm{e}$ & $51.4 \mathrm{a}$ \\
\hline BD-26 & $341 \mathrm{a}$ & $123 \mathrm{a}$ & 143 & $478 \mathrm{~b}$ & $364 \mathrm{~b}$ & $159 \mathrm{a}$ & $70 \mathrm{c}$ & $5.9 \mathrm{~d}$ & $54.1 \mathrm{a}$ \\
\hline BD-13 & $300 \mathrm{~b}$ & $124 \mathrm{a}$ & 82 & $471 \mathrm{~b}$ & $358 \mathrm{~b}$ & $119 \mathrm{~d}$ & $69 \mathrm{c}$ & $5.8 \mathrm{~d}$ & $41.3 \mathrm{~b}$ \\
\hline BD-17 & $274 \mathrm{c}$ & $116 \mathrm{~b}$ & 78 & $447 \mathrm{c}$ & $357 \mathrm{~b}$ & $126 \mathrm{c}$ & $70 \mathrm{c}$ & $5.9 \mathrm{~d}$ & $38.0 \mathrm{~b}$ \\
\hline BD-22 & $333 \mathrm{a}$ & $116 \mathrm{~b}$ & 103 & $470 \mathrm{~b}$ & $349 \mathrm{~b}$ & $121 \mathrm{~d}$ & $77 \mathrm{~b}$ & $6.0 \mathrm{~d}$ & $47.3 \mathrm{a}$ \\
\hline BD-24 & $299 \mathrm{~b}$ & $109 \mathrm{~b}$ & 101 & $473 \mathrm{~b}$ & $388 \mathrm{a}$ & $120 \mathrm{~d}$ & $73 \mathrm{c}$ & $6.1 \mathrm{~d}$ & $42.9 \mathrm{a}$ \\
\hline BD-54 & $289 \mathrm{c}$ & $108 \mathrm{~b}$ & 106 & $45,6 \mathrm{c}$ & $314 \mathrm{c}$ & $134 \mathrm{c}$ & $64 \mathrm{c}$ & $5.5 \mathrm{~d}$ & $45.7 \mathrm{a}$ \\
\hline BD-56 & $302 \mathrm{~b}$ & $125 \mathrm{a}$ & 126 & $43,7 \mathrm{c}$ & $330 \mathrm{c}$ & $123 \mathrm{~d}$ & $68 \mathrm{c}$ & $5.1 \mathrm{~d}$ & $50.0 \mathrm{a}$ \\
\hline BD-69 & $258 \mathrm{~d}$ & $112 \mathrm{~b}$ & 133 & $455 \mathrm{c}$ & $350 \mathrm{~b}$ & $150 \mathrm{a}$ & $88 \mathrm{a}$ & $5.9 \mathrm{~d}$ & $44.0 \mathrm{a}$ \\
\hline BD-43 & $279 \mathrm{c}$ & $117 \mathrm{~b}$ & 131 & $452 \mathrm{c}$ & $345 \mathrm{~b}$ & $160 \mathrm{a}$ & $73 \mathrm{c}$ & $5.9 \mathrm{~d}$ & $45.9 \mathrm{a}$ \\
\hline BD-44 & $226 \mathrm{e}$ & $123 \mathrm{a}$ & 81 & $487 \mathrm{a}$ & $351 \mathrm{~b}$ & $140 \mathrm{~b}$ & $81 \mathrm{a}$ & $8.2 \mathrm{~b}$ & $30.4 \mathrm{~b}$ \\
\hline BD-46 & $281 \mathrm{c}$ & $130 \mathrm{a}$ & 86 & $468 \mathrm{~b}$ & $330 \mathrm{c}$ & $114 \mathrm{~d}$ & $75 \mathrm{c}$ & $8.0 \mathrm{~b}$ & $36.6 \mathrm{~b}$ \\
\hline BD-52 & $275 \mathrm{c}$ & $127 \mathrm{a}$ & 117 & $477 \mathrm{~b}$ & $350 \mathrm{~b}$ & $154 \mathrm{a}$ & $83 \mathrm{a}$ & $9.3 \mathrm{a}$ & $37.7 \mathrm{~b}$ \\
\hline BD-35 & $334 \mathrm{a}$ & $122 \mathrm{a}$ & 73 & $464 \mathrm{~b}$ & $318 \mathrm{c}$ & $141 \mathrm{~d}$ & $78 \mathrm{~b}$ & $7.1 \mathrm{c}$ & $41.6 \mathrm{~b}$ \\
\hline Brazlândia Rosada & $340 \mathrm{a}$ & $131 \mathrm{a}$ & 94 & $491 \mathrm{a}$ & $344 \mathrm{~b}$ & $152 \mathrm{a}$ & $75 \mathrm{c}$ & $6.9 \mathrm{c}$ & $44.8 \mathrm{a}$ \\
\hline Average & 294 & 120 & 104 & 466 & 347 & 134 & 75 & 6.4 & 43.4 \\
\hline CV (\%) & 3,5 & 6,1 & 51,6 & 2,3 & 3,1 & 5,4 & 6,4 & 11.3 & 18.0 \\
\hline
\end{tabular}

*Significant, F test, $\mathrm{p}>0.05$; means followed by the same letter in the column do not differ from each other, Scott Knott test, $\mathrm{p}>0.05$ (significativo, teste de F, p>0,05; médias seguidas de mesma letra na coluna não diferem entre si, teste de Scott Knott, $p>0,05$ ).

Contents of acid detergent fiber (ADF) ranged from 314 to $388 \mathrm{~g} / \mathrm{kg}$ of DM. Genotypes BD-54, BD-56, BD-46, and BD-35 showed the lowest concentrations and, therefore are the most promising genotypes for silage production, as the low digestibility of ADF limits consumption by animals. In fact, ADF contents above $400 \mathrm{~g} / \mathrm{kg}$ are already adverse (Simon et al., 2009). Vine wilting under open sun tends to increase both NDF and ADF contents in forage (Quaresma et al., 2010). However, even with 24-hour wilting, NDF and ADF contents in the genotypes we studied remained at satisfactory levels for high quality forage.

High concentration of lignin reduces the fodder quality. In this study, genotype BD-31TO had the lowest lignin content, $134 \mathrm{~g} / \mathrm{kg}$ of DM. Dornas (2012) found an average value of $155 \mathrm{~g} / \mathrm{kg}$ of lignin in DM for sweet potato vines wilted for 48 hours, higher than what we currently found with 24-hour wilted vines. Loures et al. (2005) reported that lignin contents increase with wilting, thus reducing the forage nutritional value.

Wilted vines had an average ash content of $75 \mathrm{~g} / \mathrm{kg}$ of DM, varying from 64 to $88 \mathrm{~g} / \mathrm{kg}$. Dornas (2012) found a higher average value for ash contents in wilted sweet potato vines $(100 \mathrm{~g} / \mathrm{kg}$ of DM).

Genotype BD-31TO had the lowest buffering capacity (BC), $4.1 \mathrm{mg} \mathrm{HCl} / 100$ $\mathrm{g}$ of DM. Low $\mathrm{BC}$ values are favorable, since a faster decrease in $\mathrm{pH}$ restricts the growth of adverse microorganisms such as Clostridia, enterobacteria and some yeasts and fungi (Coan et al., 2007). Woolford (1984) reports that the relationship SC/BC should be below 3.0 to obtain silage of satisfactory standards. The average ratio SC/BC we observed was 1.7 , which is a good indication of the suitability of sweet potato vines to silage.

Genotypes BD-31TO, BD-26, BD-22, BD-24, BD-54, BD-56, BD69, BD-43, and cultivar Brazlândia Rosada showed the highest fermentative capacity of wilted vines (FC), above 42.9. Dornas (2012), evaluating FC in 48-hour wilted and non-wilted sweet potato vines, found a general average of 37.2 , below the average in our research (43.4). All genotypes mentioned above have satisfactory FC, since Oude Elferink et al. (1999) established 35 as the lower limit to obtain lactic silage.

There were significant differences for all traits under evaluation, except for water soluble carbohydrates, in the silage of wilted vines (Table 3).

Dry matter (DM) concentration in the silage ranged from 223 to $323 \mathrm{~g} /$ kg. Genotype BD-22 had the highest DM, while genotypes BD-69 and BD-43, the lowest concentrations, respectively 223 and $230 \mathrm{~g} / \mathrm{kg}$. Dornas (2012), in his research with silage of sweet potato vines wilted for 48 hours, found close values, ranging from 204 to $274 \mathrm{~g} / \mathrm{kg}$. Among the several factors that can drive DM variability in silage of sweet potato vines, genotypes, site conditions and climate during 
Table 3. $\mathrm{DM}=$ average concentration of dry matter (concentração média de matéria seca), $\mathrm{CP}=$ crude protein (proteína bruta), WSC $=$ water soluble carbohydrates (carboidratos solúveis), $\mathrm{NDF}=$ neutral detergent fiber (fibra em detergente neutro), $\mathrm{ADF}=$ acid detergent fiber (fibra em detergente ácido), $\mathrm{LIG}=$ lignina (lignina), and $\mathrm{ASH}=$ ash (cinzas) and $\mathrm{pH}$ in silage of wilted vines of sweet potato ( $\mathrm{pH}$ em silagens de ramas emurchecidas de batata-doce). Diamantina, UFVJM, 2011.

\begin{tabular}{|c|c|c|c|c|c|c|c|c|}
\hline \multirow{2}{*}{ Genotype } & \multirow{2}{*}{$D M^{*}(g / \mathbf{k g})$} & $\mathrm{CP}^{*}$ & $\mathbf{W S C}^{\text {ns }}$ & NDF* $^{*}$ & ADF* & LIG* $^{*}$ & ASH* & \multirow{2}{*}{$\mathrm{pH}^{*}$} \\
\hline & & \multicolumn{6}{|c|}{ (g/kg DM) } & \\
\hline BD-31TO & $266 \mathrm{~d}$ & $106 \mathrm{~b}$ & 23 & $469 \mathrm{~d}$ & $385 \mathrm{e}$ & $114 \mathrm{~b}$ & $3 \mathrm{~b}$ & $3.9 \mathrm{~b}$ \\
\hline BD-26 & $308 \mathrm{~b}$ & $119 \mathrm{a}$ & 62 & $500 \mathrm{~b}$ & $438 \mathrm{~b}$ & $150 \mathrm{a}$ & $64 \mathrm{c}$ & $4.4 \mathrm{a}$ \\
\hline BD-13 & $265 \mathrm{~d}$ & $107 \mathrm{~b}$ & 74 & $507 \mathrm{~b}$ & $394 \mathrm{e}$ & $116 \mathrm{~b}$ & $67 \mathrm{c}$ & $4.0 \mathrm{~b}$ \\
\hline BD-17 & $294 \mathrm{c}$ & $112 \mathrm{~b}$ & 76 & $486 \mathrm{c}$ & $416 \mathrm{c}$ & $128 \mathrm{~b}$ & $62 \mathrm{c}$ & $3.8 \mathrm{~b}$ \\
\hline BD-22 & $323 \mathrm{a}$ & $106 \mathrm{~b}$ & 85 & $506 \mathrm{~b}$ & $476 \mathrm{a}$ & $121 \mathrm{~b}$ & $75 \mathrm{~b}$ & $4.1 \mathrm{~b}$ \\
\hline BD-24 & $288 \mathrm{c}$ & $115 \mathrm{a}$ & 73 & $509 \mathrm{~b}$ & $417 \mathrm{c}$ & $129 \mathrm{~b}$ & $67 \mathrm{c}$ & $4.0 \mathrm{~b}$ \\
\hline BD-54 & $260 \mathrm{~d}$ & $88 \mathrm{c}$ & 26 & $586 \mathrm{a}$ & $420 \mathrm{c}$ & $123 \mathrm{~b}$ & $56 \mathrm{c}$ & $3.9 \mathrm{~b}$ \\
\hline BD-56 & $274 d$ & $136 \mathrm{a}$ & 34 & $513 \mathrm{~b}$ & $402 \mathrm{~d}$ & $117 \mathrm{~b}$ & $63 \mathrm{c}$ & $3.9 \mathrm{~b}$ \\
\hline BD-69 & $223 \mathrm{f}$ & $111 \mathrm{~b}$ & 48 & $489 \mathrm{c}$ & $418 c$ & $119 \mathrm{~b}$ & $82 \mathrm{a}$ & $3.8 \mathrm{~b}$ \\
\hline BD-43 & $230 \mathrm{f}$ & $110 \mathrm{~b}$ & 68 & $513 \mathrm{~b}$ & $418 c$ & $127 \mathrm{~b}$ & $65 \mathrm{c}$ & $3.7 \mathrm{~b}$ \\
\hline BD-44 & $242 \mathrm{e}$ & $108 \mathrm{~b}$ & 40 & $449 \mathrm{~d}$ & $407 \mathrm{~d}$ & $100 \mathrm{~b}$ & $65 \mathrm{c}$ & $3.9 \mathrm{~b}$ \\
\hline BD-46 & $269 \mathrm{~d}$ & $106 \mathrm{~b}$ & 56 & $517 \mathrm{~b}$ & $421 \mathrm{c}$ & $140 \mathrm{a}$ & $69 \mathrm{c}$ & $4.0 \mathrm{~b}$ \\
\hline BD-52 & $249 \mathrm{e}$ & $108 \mathrm{~b}$ & 31 & $444 \mathrm{e}$ & $399 \mathrm{~d}$ & $118 \mathrm{~b}$ & $62 \mathrm{c}$ & $4.4 \mathrm{a}$ \\
\hline BD-35 & $303 \mathrm{~b}$ & $108 \mathrm{~b}$ & 38 & $471 \mathrm{~d}$ & $414 \mathrm{c}$ & $140 \mathrm{a}$ & $74 \mathrm{~b}$ & $4.0 \mathrm{~b}$ \\
\hline Brazlândia Rosada & $287 \mathrm{c}$ & $113 \mathrm{a}$ & 43 & $482 \mathrm{c}$ & $417 \mathrm{c}$ & $119 \mathrm{~b}$ & $73 \mathrm{~b}$ & $4.1 \mathrm{~b}$ \\
\hline Average & 272 & 109 & 52 & 498 & 416 & 126 & 68 & 4.0 \\
\hline CV (\%) & 2,9 & 4,4 & 52,7 & 1,7 & 1,6 & 4,0 & 6,3 & 2.3 \\
\hline
\end{tabular}

*Significant, F test, $\mathrm{p}>0.05$; means followed by the same letter in the column do not differ from each other, Scott Knott test, $\mathrm{p}>0.05$ (significativo, teste de F, p>0,05; médias seguidas de mesma letra na coluna não diferem entre si, teste de Scott Knott, $\mathrm{p}>0,05$ ).

plant growth, growing season, and the storage period and conditions stand out. There was variation also between DM concentration in the wilted vines and in the silage obtained out of them. In average, DM concentration tended to decrease, genotype BD-26 showing the largest drop: DM fell from $341 \mathrm{~g} / \mathrm{kg}$ on wilted vines to $308 \mathrm{~g} / \mathrm{kg}$ in the silage.

Crude protein (CP) in vine silages ranged from 88 to $136 \mathrm{~g} / \mathrm{kg}$ of DM. Genotypes BD-26, BD-24, BD-56, and Brazlândia Rosada significantly outstood the others. Dornas (2012) and Figueiredo et al. (2012), evaluating sweet potato genotypes, found average $\mathrm{CP}$ concentration in vine silages of 127 and $116 \mathrm{~g} / \mathrm{kg}$ respectively.

The average concentration of water soluble carbohydrates (WSC) we found in vine silages was $52 \mathrm{~g} / \mathrm{kg}$ of DM, with no significant differences among genotypes. Dornas (2012) found a SC average concentration of $42 \mathrm{~g} / \mathrm{kg}$ in vine silages. This value, lower to that we are currently reporting, is probably related to the longer vine wilting period in Dornas (2012), since sugars are consumed during wilting by fungi and yeasts (Santos et al., 2010). WSC concentration was reduced during the silage process from $104 \mathrm{~g} / \mathrm{kg}$ of $\mathrm{DM}$ in wilted vines to $52 \mathrm{~g} / \mathrm{kg}$ in the silage, or $50.5 \%$ reduction in relation to the average initial concentration. Considering that SC are consumed by lactic acid bacteria and converted into organic acids, especially lactic acid, this reduction was already expected (Oliveira et al., 2007; Santos et al., 2010).

The neutral detergent fiber (NDF) content in silages ranged from 444 to $586 \mathrm{~g} / \mathrm{kg}$ of DM. Genotype BD54 had the highest concentration, although below $600 \mathrm{~g} / \mathrm{kg}$, the limit recommended by Van Soest (1994) to avoid consumption limitation by animals due to NDF. Monteiro et al. (2007), evaluating silage of non-wilted sweet potato vines, cultivar Brazlândia Rosada, reported a NDF concentration of $379 \mathrm{~g} / \mathrm{kg}$ of DM, below what we presently observed for the same cultivar (482 g/kg). Viana et al. (2011) found an average NDF concentration of 462 $\mathrm{g} / \mathrm{kg}$ of DM in silages of wilted vines. The fermentation process did not alter significantly NDF concentration.

Genotypes BD-31TO and BD-13 had the lowest acid detergent fiber (ADF) contents in the silage, respectively 385 and $394 \mathrm{~g} / \mathrm{kg}$ of DM. Viana et al. (2011) and Monteiro et al. (2007) found no differences among genotypes, reporting average contents of 384 and $415 \mathrm{~g} / \mathrm{kg}$ of DM in 45 and 40 days old silages, respectively. We observed that the ADF average concentration in the fodder went from 347 to $416 \mathrm{~g} / \mathrm{kg}$ of $\mathrm{DM}$ during the silage process, which is above the adequate (Simon et al., 2009). 
Therefore, ADF definitely should be looked at when choosing the genotype to use in silage production.

Genotypes BD-31TO, BD-13, BD17 , BD-22, BD-24, BD-54, BD-56, BD69, BD-43, BD-44, BD-52 and cultivar Brazlândia Rosada had the lowest lignin contents in silage and therefore are the best suited for this purpose, since lignin is an important digestibility limiting factor (Van Soest, 1994). Dornas (2012), evaluating silage of sweet potato wilted vines, found an average lignin content of $153 \mathrm{~g} / \mathrm{kg}$ of DM, higher than the average we currently found $(126 \mathrm{~g} / \mathrm{kg})$. It should be noted that both studies were carried out using the Potassium Permanganate Method, which ends up with higher values than the Klason method.

Ash content in the silage varied between 56 and $82 \mathrm{~g} / \mathrm{kg}$ of DM, with an average value of $68 \mathrm{~g} / \mathrm{kg}$. According to Lopes \& Evangelista (2010), there is a tradeoff between ash and cell contents during fermentation. In all genotypes, ash contents in silage dropped in comparison to the wilted material (Tables 2 and 3): averages of $75 \mathrm{~g} / \mathrm{kg}$ of DM in wilted vines and $68 \mathrm{~g} / \mathrm{kg}$ of DM in the silage.

Silage $\mathrm{pH}$ ranged from 3.7 to 4.4 , with an average of 4.0. This is higher than results obtained from Viana et al. (2011) who, evaluating vine silage of different sweet potato genotypes, found an average value of 3.7 , but quite similar to Dornas (2012), who reported an average of 4.1 for vine silage produced with and without microbial inoculant. According to Silva et al. (2008), pH values below 4.0, as frequently observed in silages, are the most suitable, since the acidity inhibits the growth of adverse microorganisms, such as clostridia, enterobacteria, yeast, and fungi (Coan et al., 2007).

Genotypes BD-13, BD-17, BD-54, BD-56, BD-43, BD-44, BD-46, and BD-52 showed middle to high green and dry mass yield. Genotypes differed significantly in all bromatological characteristics we studied, except carbohydrate contents in wilted vines and its respective silages. Considering wilted vines, genotypes BD-26, BD-13, BD-56, BD-46, BD-35, and cultivar Brazlândia Rosada were the most suitable for animal feeding, as far as the bromatological composition is considered. The sweet potato genotype BD-56 was the most adequate for producing silage out of vines.

\section{ACKNOWLEDGEMENTS}

To the National Council for Scientific and Technological Development (CNPq), to the Foundation for Research Support of the State of Minas Gerais (FAPEMIG), and to the Coordination for the Improvement of Higher Education Personnel (CAPES) for granting scholarships and financial resources for developing the project.

\section{REFERENCES}

ALVARES VVH; DIAS LE; RIBEIRO CA; SOUZA RB. 1999. Uso de gesso agrícola. In: RIBEIRO AC; GUIMARAES PTG; ALVAREZ VVH (eds). Recomendação para o uso de corretivos e fertilizantes em Minas Gerais: 5. Aproximação. Viçosa: Comissão de Fertilidade do Solo do Estado de Minas Gerais. p. 180.

ANDRADE JÚNIOR VC; VIANA DJS; PINTO NAVD; RIBEIRO KG; PEREIRA RC; NEIVA IP; AZEVEDO AM; ANDRADE PCR. 2012. Características produtivas e qualitativas de ramas e raízes de batata-doce. Horticultura Brasileira 30: 584-589.

AZEVEDO AM; ANDRADE JÚNIOR VC; VIANA DJS; ELSAYED AY; PEDROSA CE; NEIVA IP; FIGUEIREDO JA. 2014. Influence of harvest time and cultivation sites on the productivity and quality of sweet potato. Horticultura Brasileira 32: 21-27.

CARDOSO AD; VIANA AES; RAMOS PAS; MATSUMOTO SN; AMARAL CLF; SEDIYAMA T; MORAIS OM. 2005. Avaliação de genótipos de batata-doce em Vitória da Conquista. Horticultura Brasileira 23: 911-914.

COAN RM; REIS RA; GARCIA GR; SCHOCKEN-ITURRINO RP; FERREIRA DS; RESENDE FD; GURGEL FA. 2007. Dinâmica fermentativa e microbiológica de silagens dos capins Tanzânia e Marandu acrescidas de polpa cítrica peletizada. Revista Brasileira de Zootecnia 36: 1502-1511.

DORNAS MFS. 2012. Seleção de genótipos de batata-doce para a produção de silagem de ramas. 2012. Diamantina: UFVJM. 51p (Dissertação mestrado).

EMBRAPA. 2006. Centro Nacional e Pesquisa em Solos. (Sistema Brasileiro de Classificação de Solos). Brasília: Embrapa-SPI. 306p.

FERREIRA DF. 2011. Sisvar: A computer statistical analysis system. Ciência e Agrotecnologia 35: 1039-1042.
FIGUEIREDO JA; ANDRADE JÚNIOR VC; PEREIRA RC; RIBEIRO KG; VIANA DJS; NEIVA IP. 2012. Avaliação de silagens de ramas de batata-doce. Horticultura Brasileira 30: 708-712.

FREITAS AWP; PEREIRA JC; ROCHA FC; COSTA MG; LEONEL FP; RIBEIRO MD. 2006. Avaliação da qualidade nutricional da silagem de cana-de-açúcar com aditivos microbianos e enriquecida com resíduo da colheita de soja. Revista Brasileira de Zootecnia 35: 38-47.

HAIGH PM. 1990. Effect of herbage watersoluble carbohydrate content and water conditions at ensilage on the fermentation of grass silages made on commercial farms. Grass and Forage Science 45: 263-271.

LOPES J; EVANGELISTA AR. 2010. Características bromatológicas, fermentativas e população de leveduras de silagens de cana-de-açúcar acrescidas de ureia e aditivos absorventes de umidade. Revista Brasileira de Zootecnia 39: 984-991.

LOURES DRS; NUSSIO LG; PAZIANI SF; PEDROSO AF; MARI LJ; RIBEIRO JL; ZOPOLLATTO M; SCHMIDT P; JUNQUEIRA MC; PACKER IU; CAMPOS FP. 2005. Composição bromatológica e produção de efluente de silagens de CapimTanzânia sob efeitos do emurchecimento, do tamanho de partícula e do uso de aditivos biológico. Revista Brasileira de Zootecnia 34: 726-735.

MONTEIRO AB; MASSAROTO JA; GASPARINO CF; SILVA RR; GOMES LAA; MALUF WR; SANTOS FILHO JC. 2007. Silagens de cultivares e clones de batata doce para alimentação animal visando sustentabilidade da produção agrícola familiar. Revista Brasileira de Agroecologia 2: 978981.

OLIVEIRA JS; SANTOS EM; ZANINE AM; MANTOVANI HC; PEREIRA OG; ROSA LO. 2007. Populações microbianas e composição química de silagem de capimmombaça (Panicum maximum) inoculado com Streptococcus bovis isolado de rúmen. Archives of Veterinary Science 12: 35-40.

OUDE ELFERINK SJWH; DRIEHUIS F; KROONEMAN J; GOTTSCHAL JC; SPOELSTRASF. 1999. Lactobacillus buchneri can improve the aerobic stability of silage via a novel fermentation pathway: the anaerobic degradation of lactic acid to acetic acid and 1,2-propanediol. In: INTERNATIONAL SILAGE CONFERENCE, 12. Anais... Uppsala: Swedish University of Agricultural Science. p. 266-267.

PESCE DMC; GONCALVES LC; RODRIGUES JAS; RODRIGUEZ NM; BORGES I. 2000. Análise de vinte genótipos de sorgo (Sorghum bicolor), de portes médio e alto, pertencentes ao ensaio nacional. Revista Brasileira de Zootecnia 29: 978-987.

PLAYNE MJ; MCDONALD P. 1966. The buffering constituints of herbage. Journal of the Science of Food and Agriculture 17: 264-268.

QUARESMA JPS; ABREU JG; ALMEIDA RG; CABRAL LS; OLIVEIRA MA; RODRIGUES 
RC. 2010. Recuperação de matéria seca e composição química de silagens de gramíneas do gênero Cynodon submetidas a períodos de pré-emurchecimento. Ciência e Agrotecnologia 34: 1232-1237.

SANTOS MVF; GÓMEZ CASTRO AG; PEREA JM; GARCÍA A; GUIM A; PÉREZ HERNÁNDEZ M. 2010. Fatores que afetam o valor nutritivo das silagens de forrageiras tropicais. Archivos de Zootecnia 59: 26-26.

SILVA MAA; FURLAN AC; MOREIRA I; PAIANO D; SCHERER C; MARTINS EN.
2008. Avaliação nutricional da silagem de raiz de mandioca contendo soja integral para leitões na fase inicial. Revista Brasileira de Zootecnia 37: 23-26.

SILVA DJ; QUEIROZ AC. 2002. Análise de alimentos: métodos químicos e biológicos. Viçosa: UFV. 235p.

SIMON JE; LOURENCCO JÚNIOR JB; FERREIRA GDG; SANTOS NFA; NAHUM BS; MONTEIRO EMM. 2009. Consumo e digestibilidade de silagem de sorgo como alternativa para alimentação suplementar de ruminantes na Amazônia oriental. Amazônia:
Ciência \& Desenvolvimento 4: 28-30.

VAN SOEST PJ. 1994. Nutricional ecology of the ruminant. Cornell: Cornell University Press. 476p.

VIANADJS; ANDRADE JÚNIOR VC; RIBEIRO KG; PINTO NAVD; NEIVAIP; FIGUEIREDO JA; LEMOS VT; PEDROSA CE; AZEVEDO AM. 2011. Potencial de silagens de ramas de batata-doce para alimentação animal. Ciência Rural 41: 1466-1471.

WOOLFORD MK. 1984. The silage fermentation. New York: Marcel Dekker, 305p. 